4 US Surgeon General. Report. Smoking and health. Washington, DC: US Government Printing Office, 1979.

${ }^{5}$ Russell MAH, Wilson C, Patel UA, Cole PV, Feyerabend C. Comparison of the effect on tobacco consumption and carbon monoxide absorption of changing to high and low nicotine cigarettes. $\mathrm{Br} M e d \mathcal{F} 1973$;iv:512-6.

- Russell MAH, Wilson C, Patel UA, Cole PV, Feyerabend C. Plasma nicotine levels after smoking cigarettes with high, medium, and low nicotine yields. $\mathrm{Br} \mathrm{Med} \mathcal{F} 1975$;ii:414-6.

${ }^{7}$ Russell MAH. Self-regulation of nicotine intake by smokers. In: Battig, $\mathrm{K}$, ed. Behavioral effects of nicotine. Basle: Karger, 1978:108-22.

${ }^{8}$ Sutton SR, Feyerabend C, Cole PV, Russell MAH. Adjustment of smokers to dilution of tobacco smoke by ventilated cigarette holders. Clin Pharmacol Ther 1978;24:395-405.

- Schachter S. Nicotine regulation in heavy and light smokers. $\mathcal{F}$ Exp Psychol [Gen] 1977;106:5-12.

10 Ashton H, Stepney R, Thompson JW. Self-titration by cigarette smokers. Br Med F 1979;ii:357-60.

${ }^{11}$ Creighton DE, Lewis PH. The effect of different cigarettes on human smoking patterns. In: Thornton RE, ed. Smoking behaviour: physiological and psychological influences. London: Churchill Livingstone, 1978: 289-300.

12 Thornton RE, ed. Smoking behaviour: physiological and psychological influences. London: Churchill Livingstone, 1978.

13 Russell MAH, Cole PV, Brown E. Absorption by non-smokers of carbon monoxide from room-air polluted by tobacco smoke. Lancet 1973;i: 576-9.

14 Feyerabend C, Russell MAH. Improved gas-chromatographic method and micro-extraction technique for the measurement of nicotine in biological fluids. F Pharm Pharmacol 1979;31:73-6.

15 Winer BJ. Statistical principles in experimental design. New York: McGrawHill, 1962:298.

16 Lee PN, ed. Statistics of smoking in the United Kingdom. Research paper 1. 7th ed and supplements. London: Tobacco Research Council, 1976.
17 Wald N, Howard S, Smith PG, Bailey A. Use of carboxyhaemoglobin levels to predict the development of diseases associated with cigarette smoking. Thorax 1975;30:133-40.

18 Russell MAH, Feyerabend C. Cigarette smoking: a dependence on highnicotine boli. Drug Metab Rev 1978;8:29-57.

19 Wald N, Idle M, Smith PG. Carboxyhaemoglobin levels in smokers of filter and plain cigarettes. Lancet 1977;i:110-2.

${ }^{20}$ Rawbone RG, Murphy K, Tate ME, Kane SJ. The analysis of smoking parameters, inhalation and absorption of tobacco smoke in studies of human smoking behaviour. In: Thornton RE, ed. Smoking behaviour: physiological and psychological influences. London: Churchill Livingstone, 1978:171-94.

${ }^{21}$ Bross IDJ, Gibson R. Risks of lung cancer in smokers who switch to filter cigarettes. Amer $\mathcal{F}$ Public Health 1968;58:1396-403.

22 Wynder EL, Mabuchi K, Beattie EJ. The epidemiology of lung cancer: recent trends. F $A M A$ 1970;213:2221-8.

${ }^{23}$ Hammond EC, Garfinkel L, Seidman H, Lew EA. Tar and nicotine content of cigarette smoke in relation to death rates. Environ Res 1976; 12:263-74.

${ }^{24}$ Dean G, Lee PN, Todd GF, Wicken AJ. Report on a second retrospective mortality study in north east England. Part 1. Research paper 14 London: Tobacco Research Council, 1977.

25 Auerbach O, Hammond EC, Garfinkel L. Changes in bronchial epithelium in relation to cigarette smoking, 1955-1960 vs 1970-1977. N Engl f Med $1979 ; 300: 381-6$.

${ }^{26}$ Gori GB. Low-risk cigarettes : a prescription. Science 1976;194:1243-6.

27 Russell MAH. Low-tar, medium-nicotine cigarettes: a new approach to safer smoking. $\mathrm{Br}$ Med $\mathcal{f} 1976 ; \mathrm{i}: 1430-3$.

${ }^{28}$ Draper NR, Smith H. Applied regression analysis. Toronto: Wiley, 1967: 163.

(Accepted 18 fanuary 1980)

\title{
Can insulin-treated diabetics be given beta-adrenergic blocking drugs?
}

\section{Summary and conclusions}

Lack of awareness of hypoglycaemia leading to loss of consciousness is a serious problem in some insulintreated diabetics, and beta-blocking drugs may increase this hazard. A prospective study was therefore carried out over eight months to determine the incidence of hypoglycaemic episodes in 50 insulin-treated diabetics taking beta-blockers as compared with 100 diabetic controls matched for age, sex, and duration of diabetes. The incidence of loss of consciousness from hypoglycaemia was the same in both groups and was unrelated to the dose of beta-blocking drug used. Five patients taking beta-blockers and 10 controls had episodes of unconsciousness, but four of these patients taking betablockers had had similar episodes in the two years preceding treatment.

It is concluded that beta-blocking drugs are generally safe in insulin-treated diabetics and that hypoglycaemic unconsciousness resulting from their use is rare.

Diabetic Department, King's College Hospital, London SE5 9RS ANTHONY H BARNETT, BSC, MRCP, registrar (present appointment: MRC Research Fellow)

DAVID LESLIE, MRCP, MRC Research Fellow

PETER J WATKINS, MD, FRCP, consultant

\section{Introduction}

Beta-adrenergic blocking agents are an important advance in the management of hypertension and ischaemic heart disease. Concern has been expressed, however, about using these agents in insulin-treated diabetics because they might possibly reduce or eliminate the warning symptoms of hypoglycaemia, which are partly due to adrenergic stimulation. Hypoglycaemic loss of consciousness has been reported in an insulin-dependent diabetic taking beta-blocking drugs, ${ }^{1}$ but the extent of this problem is unknown.

We conducted a prospective investigation to discover the incidence of unconsciousness from hypoglycaemia in insulintreated diabetics receiving beta-blocking drugs compared with matched controls.

\section{Patients and methods}

We studied for eight months 50 insulin-treated diabetics taking beta-adrenergic blocking drugs. Forty-three were taking noncardioselective drugs and seven cardioselective drugs (acebutalol or metoprolol). Thirty-six of the patients were being treated for hypertension, 10 for angina, two for arrhythmias, and two for anxiety. One hundred insulin-treated diabetics who were not taking betablocking drugs served as controls and were selected consecutively to match for age, sex, and duration of diabetes.

The patients were each given a diary card on which to record details of episodes that they considered to be hypoglycaemic. We kept a separate card to record the details of each patient and the nature of each hypoglycaemic episode. Particular attention was paid 
to the cause of each hypoglycaemic attack, warning symptoms, and loss of consciousness. Loss of consciousness was recorded whenever intravenous glucose had been given or the episode witnessed.

All results were analysed by the $\chi^{2}$ test.

\section{Results}

There was no significant difference in age or duration of diabetes between the two groups. The mean age $( \pm S D)$ of the diabetics taking beta-blockers was $55 \cdot 3 \pm 12 \cdot 5$ (range 27-76) years compared with $52 \cdot 0 \pm 14 \cdot 2$ (range $25-76$ ) years for the controls. The mean duration of diabetes was $21 \cdot 3 \pm 10 \cdot 4$ (range 4-48) years and $20 \pm 9 \cdot 9$ (range 4-47) years respectively.

The incidence of hypoglycaemic loss of consciousness was $10 \%$ in both groups, with episodes occurring in five of the patients taking beta-blockers and 10 controls. Of the five patients taking betablockers, four gave a history of hypoglycaemic unconsciousness in the two years before starting the drugs; while of the 10 controls, nine gave a history of such episodes in the preceding two years. Altogether, eight episodes of unconsciousness occurred in the five patients taking beta-blockers and 13 in the 10 controls.

There was no relation between the incidence of hypoglycaemic episodes and loss of consciousness and the dose of beta-blocker (table I). Loss of consciousness occurred in four patients taking a non-cardioselective drug in a daily dosage of $40 \mathrm{mg}$ (oxprenolol) and $120 \mathrm{mg}, 120 \mathrm{mg}$, and $240 \mathrm{mg}$ (propranolol). One patient lost consciousness while taking acebutalol in a daily dose of $200 \mathrm{mg}$. In contrast, the mean dose of propranolol in those who never lost consciousness was $240 \pm 296 \mathrm{mg} /$ day (range $40-1200 \mathrm{mg} /$ day), eight of these patients taking over $240 \mathrm{mg}$ propranolol/day.

The proportions of patients experiencing hypoglycaemic episodes in the group taking beta-blockers and the controls were similar $(62 \%(31 / 50)$ and $66 \%$ respectively). The total number of hypoglycaemic episodes was 219 in the patients taking beta-blockers and 398 in the controls. Patients were asked directly whether they considered warning symptoms to be inadequate, and about $10 \%$ in each group reported this to be the case.

Hypoglycaemic episodes including loss of consciousness were unrelated to age, sex, or duration or complications of diabetes. Both sexes and all ages and durations of diabetes were represented in the five patients who lost consciousness while taking beta-blockers (table II). Only one patient lost consciousness for the first time while taking a beta-blocker (propranolol $120 \mathrm{mg} /$ day), and he also reported reduced warning symptoms of hypoglycaemia after he started the drug.

When the diabetics were studied according to the severity of microangiopathy those with severe complications (proliferative retinopathy, maculopathy, or persistent proteinuria) were no more likely to develop hypoglycaemic unconsciousness than those without complications or with only mild background retinopathy (table II).

TABLE I-Relation between episodes of hypoglycaemia and dose of beta-blocking drug. (Figures are numbers of patients)

\begin{tabular}{|c|c|c|c|c|c|c|}
\hline \multicolumn{3}{|c|}{ Dose (mg/day) } & $<80$ & $80-159$ & $160-319$ & $>320$ \\
\hline \multicolumn{7}{|c|}{ Propranolol } \\
\hline $\begin{array}{l}\text { Hypoglycaemic unconsciousness } \\
\text { Hypoglycaemia without loss of }\end{array}$ & . & . & & 2 & 1 & \\
\hline consciousness $\quad . . \quad \ldots$ & .. & & 3 & 8 & 3 & 2 \\
\hline No hypoglycaemic episodes .. & $\because$ Oror & . & 2 & 7 & 1 & 4 \\
\hline $\begin{array}{l}\text { Hypoglycaemic unconsciousness } \\
\text { Hypoglycaemia without loss of }\end{array}$ & ${ }^{*}$ & .. & 1 & & & \\
\hline $\begin{array}{l}\text { Hypoglycaemia without loss of } \\
\text { consciousness }\end{array}$ & . & . & & 2 & 2 & \\
\hline No hypoglycaemic episodes .. & . & . & & 1 & 2 & 2 \\
\hline
\end{tabular}

The proportions of patients experiencing the common symptoms of hypoglycaemia were similar in both groups. Hunger occurred in 13 patients taking beta-blockers and 32 controls, shakiness in 23 and 53 patients respectively, palpitations in 13 and 17, and mental change in 30 and 58. Only sweating differed between the two groups, being more common in the patients taking beta-blockers (41 v 59 patients; $\mathrm{p}<0.05$ )

\section{Discussion}

We designed this study to determine whether beta-adrenergic blocking drugs cause loss of consciousness from hypoglycaemia in insulin-treated diabetics. We found that diabetics taking beta-blockers were no more prone to hypoglycaemia or hypoglycaemic unconsciousness than matched diabetic controls. Out of five patients taking beta-blocking drugs who experienced loss of consciousness, four had had similar episodes when not taking the drug. Thus in only one of 50 patients might hypoglycaemic unconsciousness be attributed to use of a betablocker. We conclude that beta-adrenergic blockers are generally safe to use in insulin-treated diabetics.

Hypoglycaemic unconsciousness was unrelated to the dose of beta-blocker and occurred in those taking small and moderate amounts. Out of 45 patients who did not experience hypoglycaemic unconsciousness, eight were taking over $240 \mathrm{mg}$ propranolol/day.

Hypoglycaemic unconsciousness remains the greatest fear of most insulin-treated diabetics. It is alarmingly common, and occurred in 15 of the 150 patients in the present study in only eight months. These 15 patients also had a history of recurrent loss of consciousness before the study, which the remaining patients did not have. Although hypoglycaemic unconsciousness is generally considered to become more common with increasing age and duration of diabetes, ${ }^{2}$ those who experienced it in the present study of selected patients included both young and old patients and those with and without severe complications. Autonomic neuropathy is sometimes considered to be responsible for hypoglycaemic unconsciousness, ${ }^{23}$ although this is poorly documented and we have observed (unpublished) that some patients with severe autonomic neuropathy retain good warning symptoms of hypoglycaemia. Patients taking betablockers appear to be more likely to sweat excessively, and this has been reported by others. ${ }^{45}$

Studies on diabetics have been performed to establish the effects of selective and non-selective beta-blockers on changes in blood glucose concentrations after insulin. During insulininduced hypoglycaemia the rate of fall of blood glucose concentration is not affected by a beta-blocker. ${ }^{5-8}$ The rate of recovery of the blood glucose concentration has been reported to be unaffected ${ }^{56}$ or delayed by both selective and non-selective beta-blockers in insulin-treated diabetics, with very little difference between them, ${ }^{8}$ and even in non-diabetics the difference is small. ${ }^{910}$ The conclusion that selective betablockers are less hazardous than non-selective drugs when given to diabetics is not warranted on the basis of these studies. In the present study one of our patients taking a selective and four taking a non-selective beta-blocker experienced hypoglycaemic unconsciousness, while six taking a selective and 39 taking a non-selective drug did not.

TABLE II-Details of patients who experienced hypoglycaemic loss of consciousness during eight-month study

\begin{tabular}{|c|c|c|c|c|c|c|c|c|c|}
\hline & \multirow[b]{2}{*}{$\begin{array}{l}\text { No of } \\
\text { patients }\end{array}$} & \multirow[b]{2}{*}{$\begin{array}{c}\text { Mean age } \\
\text { (range) } \\
\text { (years) }\end{array}$} & \multirow{2}{*}{$\begin{array}{c}\text { Mean duration of } \\
\text { diabetes } \\
\text { (range) } \\
\text { (years) }\end{array}$} & \multirow[b]{2}{*}{ Sex } & \multicolumn{3}{|c|}{ Retinopathy } & \multirow[b]{2}{*}{$\begin{array}{c}\text { Diabetic } \\
\text { nephropathy }\end{array}$} & \multirow[b]{2}{*}{$\begin{array}{l}\text { Autonomic } \\
\text { neuropathy }\end{array}$} \\
\hline & & & & & Nil & $\begin{array}{l}\text { Background } \\
\text { retinopathy }\end{array}$ & $\begin{array}{l}\text { Proliferative } \\
\text { retinopathy, } \\
\text { maculopathy }\end{array}$ & & \\
\hline $\begin{array}{l}\text { Patients taking } \\
\text { beta-blockers }\end{array}$ & 5 & \multirow{2}{*}{$\begin{array}{c}54 \\
(27-70) \\
55 \\
(30-71)\end{array}$} & \multirow{2}{*}{$\begin{array}{c}20 \\
(14-26) \\
23 \\
(8-32)\end{array}$} & $3 \mathrm{~F}, 2 \mathrm{M}$ & 2 & 2 & 1 & 2 & 1 \\
\hline Controls & 10 & & & $3 \mathrm{~F}, 7 \mathrm{M}$ & 5 & 3 & 2 & 1 & 0 \\
\hline
\end{tabular}


We conclude that beta-blocking drugs are generally safe to use in insulin-treated diabetics and that hypoglycaemic unconsciousness resulting from their use is rare. Whether selectivity confers any real advantage remains uncertain. It is unnecessary to deny diabetics the therapeutic benefit of betablocking drugs.

We thank Dr D A Pyke, consultant physician to the diabetic department, for his help and encouragement in the production of this paper.

DL is supported by the MRC.

Requests for reprints should be sent to AHB.

\section{References}

${ }^{1}$ Kotler MN, Berman L, Rubenstein AH. Hypoglycaemia precipitated by propranolol. Lancet 1966 ;ii:1389-90.

2 Malins J. Clinical diabetes mellitus. London: Eyre and Spottiswoode, $1968: 434-5$
3 Sussman KE, Crout JR, Marble A. Failure of warning in insulin-induced hypoglycaemic reactions. Diabetes $1963 ; 12: 38-45$.

${ }^{4}$ Strom L. Propranolol in insulin-dependent diabetes. N Engl f Med 1978; 299:487.

5 Viberti GC, Stimmler M, Keen $\mathrm{H}$. The effect of oxprenolol and metoprolol on the hypoglycaemic response to insulin in normals and insulin dependent diabetics. Diabetologia 1978;15:278.

6 Passa P, Bouvier P, Assan R, Canivet J. Effects of acebutalol (cardioselective beta-blocker) on insulin-induced hypoglycaemia in diabetic patients. Diabetologia 1977;13:424.

7 Deacon SP, Karunanayake A, Barnett D. Acebutalol, atenolol, and propranolol and metabolic responses to acute hypoglycaemia in diabetics. Br Med f 1977 ;ii: 1255-7.

${ }^{8}$ Lager I, Blohme G, Smith U. Effects of cardioselective and non-selective $\beta$-blockade on the hypoglycaemic response in insulin-dependent diabetics. Lancet $1979 ; \mathrm{i}: 458-62$.

9 Abramson E, Arky R, Woeber K. Effects of propranolol on the hormonal and metabolic response to insulin-induced hypoglycaemia. Lancet 1966;ii:1386-8.

${ }^{10}$ Deacon S, Barnett D. Comparison of atenolol and propranolol during insulin-induced hypoglycaemia. $\mathrm{Br}$ Med f 1976;ii :272-3.

(Accepted 1 February 1980)

\title{
Altered haemorheology in oral-contraceptive users
}

\author{
PETER C BUCHAN, HAMISH N MACDONALD
}

\section{Summary and conclusions}

The haemorheological profile of the menstrual cycle was determined in 12 women who did not take oral contraceptives and compared with that in two groups of women $(n=8$ and $n=30$ ) who had been taking oral contraceptives for at least six months. Packed cell volume, platelet count, erythrocyte deformability, plasma fibrinogen concentration, and plasma and whole-blood viscosity varied cyclically throughout the menstrual cycle in the 12 non-users.

This variation was abolished by the use of oral contraceptives, and the values of these indices were raised by an amount likely to predispose to thrombosis.

\section{Introduction}

The association between arteriovenous thromboembolism and use of oral contraceptives is well established ${ }^{12}$ and has stimulated investigation into possible causative mechanisms. Contraceptive steroids increase the concentrations of many coagulation factors and reduce that of antithrombin III, ${ }^{3-5}$ increase platelet adhesiveness, ${ }^{6}$ and reduce venous flow velocity by increasing venous distensibility ${ }^{7}$ and whole-blood viscosity. ${ }^{8-10}$ All of these effects increase the risk of thromboembolism, and a full understanding of them must be based on a sound appreciation of the physiological background on which they are imposed. Little attention, however, has as yet been paid to the changes in haemorheological indices in the menstrual cycle. We have determined these changes in both users and non-users of oral contraceptives.

Department of Obstetrics and Gynaecology, St James's University Hospital, Leeds LS9 7TF

PETER C BUCHAN, BSC, MRCOG, senior registrar

HAMISH N MACDONALD, PHD, FRCOG, consultant obstetrician and gynaecologist

\section{Patients and methods}

Twenty women had blood taken at the same time of day on four occasions one week apart during their menstrual cycle. Twelve were taking no medication, and eight had been taking an oral contraceptive containing $30 \mu \mathrm{g}$ ethinyloestradiol and $250 \mu \mathrm{g}$ norgestrel for at least six months. A further 30 women who had been taking the same oral contraceptive for at least six months gave one blood sample between the seventh and twenty-first day of their cycle. All of the women were healthy volunteers, aged from 22 to 34 years, who did not smoke.

Packed cell volume and platelet count were measured with a Coulter Counter S, plasma fibrinogen concentration according to the method of Ratnoff and Menzie, ${ }^{11}$ erythrocyte deformability by a microfiltration method, ${ }^{12}$ and plasma and whole-blood viscosity with a Deer Rheometer at a shear stress of $0.057 \mathrm{~N} / \mathrm{m}^{2}\left(0.57\right.$ dynes $\left./ \mathrm{cm}^{2}\right)$ at $37^{\circ} \mathrm{C}$.

Serial data were analysed using paired $t$ tests on the mean differences between stages and cross-sectional data analysed using Student's $t$ tests.

\section{Results}

The table shows the mean values of all indices in users and nonusers of oral contraceptives and the significances of the differences between the means for adjacent stages in each group.

Packed cell volume rose to a peak at ovulation, remained high in the luteal phase, and fell at menstruation in the women who were not taking oral contraceptives. In the women taking oral contraceptives this variability was abolished. Comparing the cross-sectional data from the 30 contraceptive users with data from each stage of the cycle in non-users, the mean packed cell volume was significantly higher in the contraceptive users than in the non-users for all stages (days 1-7, $\mathrm{p}<0.01 ; 12-16, \mathrm{p}<0.05 ; 18-21, \mathrm{p}<0.01$; and $26-28, \mathrm{p}<0.05)$.

Platelet count rose to a peak at ovulation, started to fall before menstruation, and continued to fall during menstruation in non-users. In contraceptive users the count remained steady throughout the cycle, and in the cross-sectional study the mean platelet count was significantly higher in contraceptive users than in non-users on days $1-7(\mathrm{p}<0.01)$ and $26-28(\mathrm{p}<0.01)$.

Plasma fibrinogen concentration in non-users rose to a peak just before menstruation and fell after the onset of menstruation but was otherwise constant. In contraceptive users the concentration remained constant during the 21 days of treatment and then fell slightly but 